\title{
Unfair terms and standard form contracts
}

\section{Wilhelmsson, Thomas}

Edward Elgar

2018-07-27

Wilhelmsson , T \& Willett , C 2018 , Unfair terms and standard form contracts . in G Howells , I Ramsay \& T Wilhelmsson (eds), Handbook of Research on International Consumer Law . 2nd edn, Research Handbooks in International Law, Edward Elgar, Cheltenham, pp.

139-171 . https://doi.org/10.4337/9781785368219.00012

http://hdl.handle.net/10138/310233

https://doi.org/10.4337/9781785368219.00012

unspecified

acceptedVersion

Downloaded from Helda, University of Helsinki institutional repository.

This is an electronic reprint of the original article.

This reprint may differ from the original in pagination and typographic detail.

Please cite the original version. 


\title{
7. Unfair terms and standard form contracts
}

\author{
Thomas Wilhelmsson and Chris Willett
}

\section{Fairness of contracts - posing the problem}

One of the core problems both in general contract law and in particular in consumer contract law is how law should react to contract terms that appear as one-sided, unbalanced or unfair - many attributes have been used in this discourse. To what extent should unfair clauses be recognised as binding and should the law regulate such clauses in other ways? Or should one assume that contracts almost per definitionem should be regarded as balanced, as they are based on the will of the parties?

The issue of how to guarantee or promote fairness of contracts is often described in terms of dichotomies like freedom of contract versus fairness or freedom versus paternalism. However, this can oversimplify the issue. For example, to characterize procedural fairness rules as being in opposition to freedom of contract can be misleading. Rules, to be described below, that require the party using standard terms to let the other party acquaint itself with them and even to 'flag' particularly onerous terms, can equally well be understood as devices to make sure that the decision-making of the party receiving the terms is sufficiently informed and 'free' (although these rules, as well as those regulating the substance of the terms, may be viewed as a rejection of a particular form of freedom, that is, a libertarian form of freedom that emphasises self-reliant, self-interested freedom). The term 'paternalism' in a similar fashion has even been combined with libertarianism. ${ }^{1}$ In addition, the term - often used to discredit regulation in this area - is misleading. It is intended to convey a picture of the state 'paternalistically' intervening in private relationships against the will of the parties. However, even if mandatory private law rules may prevent one party relying in court on terms conflicting with those rules (that is, in fact to use the state - the pater - to enforce those terms), the parties are free to do what they want as long as they agree and there is no dispute between them. Only administrative or criminal law collective control of contract terms may be called 'paternalist' in the true sense.

1 Sunstein and Thaler claim that libertarian paternalism is not an oxymoron: C.R. Sunstein and R.H. Thaler (2003), 'Libertarian Paternalism Is Not an Oxymoron', The University of Chicago Law Review, 1159-202. More generally on the relationship between fairness and freedom, between ethics of self-interest/self-reliance, and ethics of protection, and the link to economic analysis, see C. Willett (2012) 'General Clauses and the Competing Ethics of EU Consumer Law in the UK', 71 Cambridge Law Journal, 412-440, 413-4. 
So, the issue of fairness is certainly a more complex issue than is often appreciated. The rules to be found in this area have many possible purposes that reflect different forms of justice.

First, in contract discourse the problem of unfair contract terms is often raised in connection with the issue of standard form conditions. The use of such conditions poses obvious problems for traditional contract thinking, which emphasises autonomy and the will or consent of the parties as basic legitimating factors behind the binding force of contracts. With such a starting point, how can one accept that a party, who might not even have read the conditions and knows nothing about their content, should be bound by them? If this is the perceived problem, the purpose of regulation that attempts to remedy the problem, is to safeguard the actual consent of the party, or in more general terms, the substantive freedom of contract of that party. Rules that have this aim are focused less on the content of the outcome and more on the procedure for reaching the contract. They are based on some form of procedural justice. Procedures of negotiation and information are central in such an approach.

Secondly, the focus may be on the substance of the contract rather than on the procedure of making contracts. In contract law, it is natural, as a starting point, to look at fairness with regard to the relationship between the parties to a contract. Discussions often focus on the balance between what the parties have promised to perform. It is seen as important that contracts are balanced, or rather, that they do not appear as too unbalanced. In so far as the purpose of the rules is the promotion of contractual balance with regard to the substance of contracts, the rules are based on the idea of commutative justice.

Thirdly, elements of distributive justice may occasionally become relevant in this context as well. Here, the assessment of the fairness of the contractual obligation is then not primarily related to the commutative balance between the parties, but rather is focused on enhancing the position of weak groups of citizens in comparison with other groups. A good example of such contractual social protection is the principle of social force majeure that has been used in the Nordic countries. ${ }^{2}$ According to this principle, the legal consequences of delays in payment and other performance may be mitigated, if the ultimate reasons for the delay are unfavourable changes in the consumer's health, work, housing or family situation.

Fourthly, fairness rules in contract law may be used to support other societal policies. A typical example is regulation on racism and gender equality: contracts that infringe such regulation may be considered unfair for this

2 See T. Wilhelmsson (1990), "SSocial Force Majeure" - A New Concept in Nordic Consumer Law', Journal of Consumer Policy, 13, 1-14. On how this approach is more sensitive to the realities of many long term contractual relationships, see the views of the EuSoCo group, in Luca Nogler and Udo Reifner (eds) (2014), Life Time Contracts. Social Long-term Contracts in Labour, Tenancy and Consumer Credit Law, Eleven international publishing. 
reason. ${ }^{3}$ Environmental concerns and human rights issues may influence the assessment of fairness as well.

Fairness rules, in other words, may rest on a complex web of purposes and conceptions of justice. Most national as well as international solutions contain both procedural and substantive elements. Obviously up-to-date legislation on fairness and standard form contracting would need both. Depending on where the emphasis is laid, there are different approaches to the issue in different countries. In this chapter we look at those approaches. What approaches and models do we find and how do they function?

Various techniques are used to achieve fairness in contracting. In this chapter, we will only discuss the more general methods for approaching the issue, both procedural solutions as well as the use of a general clause giving the courts the right to adjust unfair contract terms. Focused mandatory legislation outlawing certain specific terms is an efficient and much-used method to deal with the problem, but we will not discuss the use of such rules, as they often relate to particular contract types or issues, and the analysis therefore would become too detailed in this context.

A basic division of the techniques to achieve fairness relates to the essentially outmoded distinction between private law and public law. In the perspective of private law, one looks at rules to be applied in the individual contractual relationship, whilst various kinds of collective enforcement mechanisms, detached from individual parties, have appeared on the scene when contractual regulation displays more 'public' features. As we mainly discuss substantive law, whilst the issue of enforcement is dealt with in other chapters of this book, only a short section is devoted to the latter. It is needed to offer a comprehensive picture of the available techniques. However, a deeper analysis of the role of, for example, German organisational action (Verbandsklage), the UK Competition and Markets Authority, ${ }^{5}$ the Australian Competition and Consumer Commission, ${ }^{1}$ and the Nordic Consumer Ombudsmen is left to the chapters on enforcement.

\section{The consumer protection issue}

As suggested above, a fairness approach to contract terms involves seeking to do some form of justice as between the parties. In the context of consumer 
contracts, this involves focusing on problems faced by consumers, in the process leading to the contract and in relation to the actual substantive terms. In recognising and seeking to regulate these problems, a fairness approach rejects the libertarian version of freedom of contract which prioritises maximisation of self-reliant and self-interested freedom in relation to the way the contract is concluded and in relation to the substantive terms. ${ }^{6}$

First, in relation to the process leading to the contract, where standard terms are concerned there is the problem of lack of transparency. Terms may be expressed in unclear, possibly legalistic, language and in small, and otherwise difficult to read, text. There may be a considerable degree of complexity, poor structuring and poor cross-referencing. This may also be compounded by the fact that consumers have little time to read the terms before making the contract; and may have little understanding of the legal context or how the term might affect them in practice. ${ }^{7}$ Significant 'transaction costs' are involved in overcoming these problems and, in practice, these problems will usually not be overcome. ${ }^{8}$ The first consequence then will be a basic lack of informed consent and the fact that the consumer will not be aware of the risks inherent in the substantive terms. This may mean that he cannot rationally compare the terms on offer with those of other traders; that he is unaware of the need to seek to negotiate for better terms or protect his interests in some other way; and that, if he enters the contract, he does so in ignorance of important risks to which he is exposed. In addition, the lack of transparency may mean that the consumer is unaware of the terms in the contract that are advantageous to him, so that he is less likely to take advantage of these when a dispute arises. A further problem is that consumers do not tend to have experience as to the types of standard terms used; nor do they

${ }^{6}$ Of the authors, Willett has presented his views on the relationship between freedom and fairness in C. Willett (2007), Fairness in Consumer Contracts: The Case of Unfair Terms, Aldershot: Ashgate, chapter 2, and more specifically on the tension between ethics of trader self-interest/consumer self-reliance and consumer protection/need, see C. Willett, 'General Clauses and the Competing Ethics of EU Consumer Law in the UK', above, note 1. Generally on ideas of procedural and substantive fairness in US literature, see F. Kessler (1943), 'Contracts of Adhesion: Some Thoughts about Freedom of Contract', Columbia Law Review, 629-42; A. Leff (1967), 'Unconscionability and the Code: The Emperor's New Clause', University of Pennsylvania Law Review, 485-559; J. Gordley (1981), 'Equality in Exchange', California Law Review, 1587-656 and M. Eisenberg (1982), 'The Bargain Principle and its Limits', Harvard Lan Review, 741-801. Also, for a US view of the EC Unfair Contract Terms Directive, see W. Whitford (1995), 'Contract Law and the Control of Standardized Terms in Consumer Contracts: An American Report', European Review of Private Law, 193-210. For recent

work on fairness standards in the context of the new Australian regime on unfair terms (Australian Consumer Law 2010 (Cth)), see the special edition of the University of Western Australia Law Review ((2013) 37(1)): most of the contributions focus on Australian law, but there is also comparative work dealing with the UK, EU and Nigeria. On proposed fairness standards in British Columbia (Canada), see R. Bigwood (2011-2012) 'Fairness Awry? Reflections on the BCLI Report on Proposals for Unfair Contract Terms Relief', 52 Can. Bus. L.J. 197.

7 See Willett, Fairness in Consumer Contracts (2007) (note 7), 2.3.2.1.

${ }^{8}$ See T. Wilhelmsson (2006), 'Cooperation and Competition Regarding Standard Contract Terms in Consumer Contracts', European Business Law Review, 49-72, at p. 55. Willett Fairness in Consumer Contracts (2007) (note 7), at 2.4.2.2. 


\section{Handbook of research on international consumer law}

tend to have experience as to the way in which these terms are interpreted and applied in practice by traders. ${ }^{9}$

Lack of transparency also undermines competition. If the terms are not transparent and consumers cannot understand and compare the offerings of different traders, there will be no incentive for traders to compete with one another for the business of consumers. ${ }^{10}$ In this respect, the lack of transparency leads to a broader problem of market failure (on which, see further below).

Even if a consumer is aware of what a term provides for and he does not wish to agree to it or is wary of agreeing to it, it may be that the trader in question does not offer any alternative package as standard. It may also be that there is no alternative package that is offered by other traders. In addition, it will usually also be unrealistic to expect the consumer to bargain for better terms. The trader will normally refuse to countenance any change in the standard terms. This is often because it is simply inefficient to engage in bargaining over standard terms, the very purpose of which is to avoid such bargaining. Even if the trader is prepared to bargain, the consumer is not likely to be in a sufficiently strong bargaining position to persuade the trader to amend or remove a term.

As to the substance of the terms, ${ }^{11}$ consumer contracts may contain terms that seek to allow the trader to evade important responsibilities to the consumer; that impose undue burdens on the consumer; and/or that compromise particular expectations that the consumer may have based on the type of contract being entered into and other signals that he has received. These terms can be argued to be particularly problematic in that they impact the private sphere of life and cause losses that consumers may find it particularly difficult

9 See J. Wightman (2003), 'Beyond Custom: Contracts, Contexts and the Recognition of Implicit Understandings', in D. Campbell, H. Collins and J. Wightman, Implicit Dimensions of Contract, Oxford: Hart Publishing, pp. 143-86, at pp. 169-70.

10 See V. Goldberg (1974), 'Institutional Change and the Quasi-Invisible Hand', Journal of Law and Economics, 461-492, at pp. 483 et seq; M. Trebilcock (1980), 'An Economic Approach to the Doctrine of Unconscionability' in B. Reiter and J. Swann (eds), Studies in Contract Law, Toronto: Butterworths, pp. 390-421; H. Beale (1995), 'Legislative Control of Fairness: The Directive on Unfair Terms in Consumer Contracts', in J. Beatson and D. Friedmann, Good Faith and Fault in Contract Law, Oxford: Clarendon, pp. 231-61, at pp. 232-3 and Willett Fairness in Consumer Contracts (2007) (note 7), at 2.3.2.1.

11 See Willett Fairness in Consumer Contracts (2007) (note 7), at 2.4.2.1; and generally on notions of substantive unfair- ness, see P. Atiyah (1986), Essays on Contract, Oxford: Clarendon Press; H. Collins (1999), Regulating Contracts, Oxford: Oxford University Press, pp. 258-66; S. Smith (2003), Contract Theory, Oxford: Oxford University Press, pp. 352-9 and (in particular from a US perspective) Gordley (note 7) and P. Benson (2001), 'The Unity of Contract Law', in P. Benson (ed.) The Theory of Contract Law, Cambridge: Cambridge University Press, pp. 118-205. 
to absorb. In other words, there may be an impact on (and disruption to) the personal and private interests of consumers, whilst business losses are primarily to the firm rather than to private interests and also may be more easily absorbed through adjustments to prices, wages, insurance etc. ${ }^{12}$

In relation to consumer contracts, the above issues can be viewed simply as an issue of the transactions costs and lack of transparency associated with standard contracting, that is, simply as a market failure issue. In this perspective, the point being made is that were it not for the standard form process, there would be the possibility of more genuine consent and the resulting terms would be likely to better reflect the real preferences of consumers. However, the issue can also be viewed more broadly in terms of consumer protection. From this point of view, the argument is that (i) whether we call the standard terms problem a market failure issue or not, consumers need protection and (ii) consumers should also be protected from the real possibility that there may be procedural unfairness and unfairness in substance even where terms are not standard and have been negotiated. ${ }^{13}$ Of course, it is true that the biggest problem tends to

\footnotetext{
12 See Willett Fairness in Consumer Contracts (2007) (note 7), at 2.4.2.1 and Wightman (note 10), pp. 98-9.
}

${ }^{13}$ Of course, it is not possible to wholly separate approaches based on market failure and consumer protection. What the law needs to do to protect consumers may be affected by what the market can, or cannot, do (in other words, we need to consider the issue not just in the context of individual relationships, but also in the context of broader market conditions). So, it is often suggested that the market failure caused by the lack of transparency (a cause of 'information asymmetry' to use the language of economics) may be mitigated by the so-called 'active margin' of consumers. This is a section of consumers who have the time, resources and education to overcome the lack of transparency and gain a good understanding of the terms and their implications. This active margin of consumers may then exert market discipline on traders, with the result that terms are more substantively fair and/or that there is improved choice (see Trebilcock (note 11), p. 379). This may mean not only that we need to be less concerned as to problems of unfairness in substance and lack of choice; but also that it may be less important that individual consumers do not have bargaining power (given that this active margin may effectively be bargaining on behalf of the majority).

However, this all depends upon there being a sufficiently large margin of consumers that reads and digests terms and makes market choices on this basis. It must be seriously questionable as to whether such a margin will often exist. It is possible that many of those who are ready and able to take positive steps to protect their interests will tend not to do so until there is a dispute. Such consumers may well scrutinise terms and/or seek advice as to their meaning when the trader seeks to rely upon the terms. This may enable such consumers to persuade traders to agree a compromise that is more favourable than what will be achieved by those who do not scrutinise and question the terms (see J. Johnston (2006), 'The Return of Bargain: An Economic Theory of How Standard Form Contracts Enable Co-operative Negotiation between Businesses and Consmers', Michigan Law Review, 857-98, at p. 857, on traders using 'managerial discretion to renegotiate' standard terms). However, these will be individual victories 


\section{Handbook of research on international consumer law}

arise with standard contracts because it has traditionally been so common for these terms to be one-sided substantively, to contain terms that are not transparent and for there to be little difference between the standard offerings of different traders. However, even if a trader does not use standard terms, the terms he proposes may still be unclear to consumers and substantively onesided. Certainly the consumer now has a greater chance of at least focusing on what is on offer and possibly, therefore, understanding it and seeking to bargain for deletion or improvement. However, (i) it is still possible that the consumer will not understand what is on offer (due to his lesser expertise in the field) and (ii) even if he does understand, he may still lack the bargaining power to influence the negotiation (especially if he is not, as an individual, particularly important to the overall market share of the trader and if he is, as is likely, less skilled in negotiation). ${ }^{14}$ Sometimes the consumer does not even have the option of choosing another trader, if the traders on the market use relatively similar conditions.

The above discussion focuses on consumer contracts. However, it can be argued that similar unfairness problems (of lack of transparency, choice and bargaining power and of unfair substantive terms) often arise in business-tobusiness contracts. Of course, it is true that, while these various problems are likely to exist for almost all consumers, some business contractors will not be affected. Nevertheless, the problems will arise in a significant number of cases and, as with consumer contracts, the issue in commercial contracts may be viewed simply as a standard contracts/market failure problem; or unfairness can also be recognised as possible even where the contract is not standardised. On one view, a regime on standard terms should recognise the similarities between consumer and commercial contracts by subjecting both to a general clause on fairness (the flexible nature of which should be capable of taking into account those cases just mentioned - where the business subject to the terms is not in fact in need of protection). ${ }^{2}$ Another reason for such an approach is that it may actually enhance consumer protection. If a business such as a retailer of goods is protected from the economic burden of unfair terms used

and will not serve to discipline what traders offer in general (see Whitford (note 6), pp. 195-9).

The limited potential for market discipline is shown in particular by the behavioural economists who demonstrate that consumers are often likely not to scrutinise and complain about terms in as rational a manner as might be assumed (see R. Korobkin (2003), 'Bounded Rationality, Standard Form Contracts and Unconscionability', University of Chicago Law Review, 1203-95, at 1203); for instance, due to a tendency to underestimate the risk (see S. Della Vigna and U. Malmendier (2006), 'Paying Not Part 5 (78-99); and in the Australian context, A. Freilich and E. Webb (2013), 'Small Business - Forgotten and in Need of Protection from Unfairness', 37 University of Western Australia Law Review, 134. One of the functions of the Nordic general fairness model (see below section 3) is also to provide protection for small businesses, 
to Go to the Gym', American Economic Review, 694-719, at 695). On similar lines, see M.G. Faure and H.A. Luth (2011), 'Behavioural Economics in Unfair Contract Terms: Cautions and Considerations', 34 Journal of Consumer Policy, 337-358,

Generally also on these and associated issues see A. Leff (1970), 'Contract as Thing', American University Law Review, 131-57 and T.D. Rakoff (1983), 'Contracts of Adhesion: An Essay in Reconstruction', 96, Harvard Law Review, 1173-284.

14 See Willett Fairness in Consumer Contracts (2007) (note 7), at 2.4.2.2. 
by his supplier, the retailer may be less inclined to feel the need to pass on risks to consumers through the terms of his contract with the consumer. In other words, the retailer may be more likely to comply with the fairness standards imposed on these terms.

Of course, arguments can be made against the instatement of a fairness/good faith principle in commercial contracts, for example, that commercial contracting is and should be premised on an adversarial ethic, freedom-oriented autonomy, certainty, and a strong focus on particular contracting contexts; and that general fairness/good faith principles and rules are corrosive of all of these values. 15 The various opinions on this issue may be related to deeper layers of legal and business culture in different countries. It has been argued, for example, that the less fairness-friendly English tradition is connected with a more competitive business culture than that prevailing in the more cooperative German and Nordic economies. ${ }^{3}$

\section{Four basic models}

Differing assessments of the need to regulate unfair contract terms and standard form contracts, as well as various understandings of the purposes and conceptions of justice of such regulation, as outlined above, have led to very different approaches to the issue in different countries. Acknowledging that there are many variations on the regulatory themes that surface in this context, one may perhaps group the ways to deal with the issue into a couple of larger categories or models. Here four models are distinguished: the no particular problem model, the standard form contract model, the consumer protection model and the general fairness model.

As the purposes mentioned are usually intertwined in practice, the models cannot directly be tied to the conceptions of justice analysed in the previous section, even though there are some obvious connections. For example, the standard form contract model, like the no particular problem model, seems most closely connected with procedural justice, whilst the consumer protection model and the general fairness model are often more preoccupied with achieving commutative justice. The Nordic general fairness model rather eclectically includes all the above-mentioned forms of justice. Of course, in most models, at least traces of all the above-mentioned conceptions of justice can be found, as will be demonstrated later.

The no particular problem model is based on the belief that the general rules on making and applying contracts basically produce just results, in safeguarding to some extent the free will and consent of both parties and perhaps acknowledging the need to adjust the contract in case of changed circumstances. What the parties have agreed on, without fraud or force, has to be considered just, precisely because they have agreed on it, and the law should recognise their 
15 See, for example, M. Bridge (1999), 'Good Faith in Commercial Contracts', in R. Brownsword, N. Hird and G. Howells (eds) (1994), Good Faith in Contract: Concept and Context, Aldershot: Ashgate, pp. 139-164, at p. 139. 
agreement. Interference against unfair contract terms is warranted only in particular cases for particular reasons.

UK law, prior to the Unfair Contract Terms Act 1977, could be viewed as an expression of such a model because the common law and equitable rules did not regulate unfair terms in any systematic way. ${ }^{16}$ And the Unfair Contracts Terms Act did not radically change the situation. Even though this Act had a rather broad scope, as its general clause on 'reasonableness' covered both standard and individual terms in consumer contracts as well as standard terms in business contracts, still one could claim that the no particular problem model continued to apply even after the adoption of the Act, as the Act did not apply to terms imposing obligations and liabilities, but only covered exemption clauses. This situation continued until implementation of the EC Unfair Contract Terms Directive, ${ }^{17}$ which required UK law to properly regulate terms imposing oblig- ations and liabilities in consumer contracts. Recently the UK domestic approach has shown some signs of moving in the direction of other models. A decade ago, the Law Commissions proposed, with regard to commercial contracts, that there should be control not only of exemption clauses in standard form contracts but also of terms imposing obligations and liabilities, at least where the affected party is a small business; and in 2015 the UK Dept for Business Innovation and Skill (BIS) consulted on the same idea, ${ }^{18}$ although it is not clear if this idea will be taken up. However, the Law Commissions also suggested with regard to consumer contracts, that UK law should take advantage of the minimum clause in the EU Unfair Contract Terms Directive $^{19}$ and remove the exemption of individually negotiated terms, thereby adopting a more full-blooded consumer protection model ${ }^{20}$ This has now been done. The new UK Consumer Rights Act which now contains the regime implementing the Directive, does not contain the individually negotiated term exemption.

The standard form contract model is a developed version of the general contract law approach. In this model, the reality of contractual consent in relation to standard form contracts is problematised. Problems of unfair- ness appear that cannot be remedied with the help of general contract law rules alone. Particular regulation of standard form contracts is required.

The most well-known example of national regulation focusing on standard form conditions is the German Act on General Conditions from 1976. ${ }^{21}$ This

${ }^{16}$ So, for example, the unconscionability rule discussed below set a very low standard and other rules tended to apply to particular aspects (such as the process of agreement - on which see below - or specific types of term such as penalty clauses and other agreed remedies - see Willett, Fairness in Consumer Contracts (2007) (note 7), at 8.1). Statutory intervention was limited to control of specific types of exclusion clause, for example, the controls on excluding or restricting the implied terms as to title, description, quality and fitness introduced by the Supply of Goods (Implied Terms) Act 1973.

17 Directive 93/13/EEC of 5 April 1993 on unfair terms in consumer contracts.

18 See Law Commissions (note 15)( the joint Report by the English and Scottish Law Commissions (2005), at 78-99; BIS, Protection of Small Businesses when

Purchasing Goods and Services (2015), London: BIS, 6,13, 16, 21 \& 27.

19 See Article 8.

20 Law Commissions, supra, at 31-2. See further below on the exemption of individually negotiated 
terms from the Directive.

21 Gesetz zur Regelung des Rechts der Allgemeinen Geschäftsbedingungen, BGB1 76 I 3317. 
Act, which dealt both with the problem of incorporation and interpretation of standard form conditions, as well as with the fairness problem, only applied to standard form conditions (general contract conditions). It did not relate to consumer protection in partic- ular, but was based on the recognition of a partial market failure occurring when standard terms are used. It controlled standard terms in both consumer and commercial contracts. ${ }^{22}$ Later, in the German Schuldrechtsreform, these provisions were included in the Civil Code (Bürgerliches Gesetzbuch) in a specific chapter on general contract conditions. ${ }^{23}$ Provisions on general condi- tions (algemene voorwaarden) have been included in a specific part of the modern Dutch Civil Code as well. ${ }^{24}$

The German Act has had a strong influence on the content of the EU Unfair Contract Terms Directive. The preparation of the Directive started from the assumption that all consumer contracts, both standard form contracts and individually negotiated contracts, should be covered. ${ }^{25}$ However, this was criticised, especially in German doctrine: the fairness control of individually negotiated contracts was said to be in conflict with private autonomy and the functioning of the market economy. ${ }^{26}$ This criticism led to the result that the scope of application of the adopted Directive was restricted to contracts which have 'not been individually negotiated' ${ }^{27}$

The consumer protection model rather looks at the typical imbalance between the parties in the consumer market. The basic ethos of such a model is consumer protection. The starting point is not the perceived conflict between contractual will and superimposed standard terms, but rather the typified strength of bargaining power of consumers as compared to traders. The delimiting criterion for protective measures in this model is the consumertrader relationship rather than the way in which the contract was made (individually or based on standard terms).

Admittedly, in practice it is not always easy to distinguish the models, and they can be combined. Such a combination has expressly been used in the EU Unfair Contract Terms Directive, as its scope is delimited both by reference to standard terms (more specifically: terms not individually negotiated) and to

${ }^{22}$ See for example R. Zimmermann (2005), 'Consumer Contract Law and General Contract Law: The German Experience', Current Legal Problems, 415-89, at 431-35.

23 Gesetz zur Modernisierung des Schuldrechts, BGB Articles 305-10.

24 See the Dutch Civil Code, Articles 6:231-247.

25 See the 1990 proposal: OJ 1990 C243/3.

${ }^{26}$ H.E. Brandner and P. Ulmer (1991), 'The Community Directive on Unfair Terms in Consumer Contracts: Some Critical Remarks on the Proposal Submitted by the EC Commission', Common Market Law Review, 647-62, at 652 et seq.

27 Article 3. 
consumer relationships. However, as the Directive was prepared solely with consumer relationships as its object of regulation, the Directive as to its content appears as a good example of the consumer protection model. The conception of 'consumer' that the Directive uses is rather absolute, as it excludes those businesses that buy for any significant business purpose, ${ }^{28}$ in contrast to those definitions that view a business as a consumer when the business buys outside its normal field. ${ }^{29}$

The French approach has followed the consumer protection model even more clearly. It applies the controls over unfair terms only to consumer contracts, but includes within these controls individually negotiated (that is, non-standard) terms. ${ }^{30}$

Finally, the general fairness model is the most far-reaching, including both consumer relationships and business-to-business relationships within the scope of fairness rules, and extending those rules to cover not only standard terms but also individually negotiated terms. Such a model recognises that the contract mechanisms can lead to unfair results in all kinds of relationships and with regard to all kind of terms, and underlines that the enforcement machinery of the state should not be made available to put into effect contracts that are considerably unfair. The principle of fairness therefore is not a limited principle for consumer relations or standard form contracting, but it should permeate the whole contract law.

A well-known example of legislation that is based on the general fairness model is that contained in Nordic contract law. Probably the most (internationally) well-known provision in Nordic contract law is the general clause in $\S 36$ of the Nordic Contract Acts, ${ }^{31}$ according to which a court may set aside or adjust a contract term, if its application leads to unfair results. As the general clause focuses on the consequences of application of a term, the courts can make use of it both when a term was unfair already when the contract was made and when a change of circumstances leads to unfairness. Of course, even though the general clause is generally applicable, a considerable part of the

${ }^{28}$ See Article 2(b) and the discussion by P. Nebbia (2007), Unfair Contract Terms in European Law, Oxford: Hart Publishing, pp. 71-8.

${ }^{29}$ See the approach taken by the English Court of Appeal in $R \& B$ Customs Brokers v. UTD [1988] 1 WLR 321.

${ }^{30}$ Loi Scrivener 1978 and now Code de la Consommation, Article L212-1.

${ }^{31}$ In Sweden, Lag om avtal och andra rättshandlingar på förmögenhetsrättens område (1915:218), the general clause added by Act 1976:185; in Finland, Laki varallisuusoikeudellisista oikeustoimista (228/1929), the general clause added by Act 956/82; in Norway, Avtaleloven (1918/4), the general clause added by Act 1983/160; and in Denmark, Lov om aftaler og andra retshandler på formuerettens område $(1986 / 600)$. 
case-law concerns consumer contracts. However, many interesting decisions concerning business-to-business contracts have been made as well.

UK, German, European and Nordic law can in other words be used as paradigmatic examples of the four models. Other examples from various jurisdictions are added in the following section. As the consumer protection model - in use in the EU Directive - is of central interest in the present Handbook, dealing with consumer law issues, this will be described in somewhat more detail in the next sections of the chapter. In addition, these sections will refer to consumer protection elements in the other models in various countries.

\section{Purely procedural protection}

In particular, in the standard form contract model, the focus of the regulation is on the procedural issue, that is how and to what extent standard terms developed by one party become binding for the other party. Rules concerning incorporation of the terms into the contract are developed to deal with this problem. These rules may be supplemented for example by rules on interpretation that regard the procedure in which the contract was made (the use of standard terms) as an important factor in determining the content of the contract. Of course, also in countries in which the basic approach to these issues rather follows the 'no particular problem' model, the consumer protection model or the general fairness model, one can usually find at least some rules or practices on standard terms of this procedural kind.

In practice, there are many ways for a party to attempt to incorporate standard form conditions into an individual contract, ranging from having the conditions printed in the contract document to only short - or in some cases even implied - references to the conditions in the contract or on some ticket, notice or other document available at the time of making the contract. This is not the place to discuss the specific legal niceties of the techniques of incorporation found in various jurisdictions. Instead, we can take a closer look at some more or less common general solutions which are designed to create some consistency between the recognition of standard form conditions and the requirement of contractual consent, that is, to address the problems of lack of transparency discussed above.

From a practical point of view, it is obviously impossible to require genuine consent in all cases when standard terms are used, in the sense that a party should have read the terms, understood them and accepted them. In many situations, parties do not bother to read the terms, and probably even should not bother to do so. ${ }^{4}$ On the other hand, it would not be acceptable to give force to more or less 'secret' norms that are totally beyond the reach of the party. Consequently, the usual compromise solution is to construct a kind of potential consent. It is seen as a minimum requirement for the conditions to become binding on a party that this party has had at least an opportunity to acquaint itself with the conditions when the contract was made. condition-reading. Strangely, consumer economics often neglects the important issue of consumer transaction costs. 
In fact, such a rule is applied in many countries. German law expressly requires that a party shall have a reasonable opportunity to become acquainted with the conditions in order to be bound by them. ${ }^{32} \mathrm{~A}$ similar rule can be found in the Dutch Civil Code. ${ }^{33}$ The doctrine and practice in the Nordic countries have developed along the same lines. ${ }^{34}$ Even secondary EU law recognises, at least indirectly, the need to have access to the standard form conditions. In the Annex to the Unfair Contract Terms Directive, which contains an 'indicative' list of terms that may be regarded as unfair, example (i) refers to a term which has the object or effect of 'irrevocably binding the consumer to terms with which he had no real opportunity of becoming acquainted before the conclusion of the contract'. The EU Electronic Commerce Directive, again, even requires that the conditions 'must be made available in a way that allows him [the recipient] to store and reproduce them'. ${ }^{35}$ Although there are jurisdictions where this requirement of possibility of acquaintance has not been adopted, ${ }^{36}$ it seems justified as a minimum rule if one wishes to respect, at least as a fiction, the ideas behind the traditional procedural contract paradigm.

32 After the Schuldrechtsreform, this provision is in BGB $\S 305(2)$ : 'die Möglichkeit . . . in zumutbarer Weise . . . von ihrem Inhalt Kenntnis zu nehmen' (own translation: 'reasonable opportunity to take note of the contents'). On US law on incorporation, see s. 203 of the Restatement of contracts.

33 Article 6:233(b).

${ }^{34}$ For example, U. Bernitz (1993), Standardavtalsrätt, 6th edition, Stockholm: Marknadsrättsförlaget, p. 32 and T. Wilhelmsson (2008), Standardavtal och oskäliga avtalsvillkor, 3rd edition, Helsingfors: Talentum, p. 69.

35 Directive 2000/31/EC of the European Parliament and of the Council of 8 June 2000 on certain legal aspects of information society services, in particular electronic commerce, in the Internal Market (Directive on electronic commerce), OJ 2000, L178/1, Article 10(3).

${ }^{36}$ In English law, for example, terms can sometimes be incorporated merely by reference even though there may have been no real opportunity to become acquainted with them. See Thompson v. LMS [1930] 1 KB 41 and J. Adams (1994), 'Unconscionability and the Standard Form Contract', in R. Brownsword, G. Howells and T. Wilhelmsson (eds), Welfarism in Contract Law, Aldershot: Dartmouth, pp. 230-47, at p. 243. However, even in English law the 'red hand' rule discussed below now applies where appropriate. In US law, a very unorthodox form of 'consent' has been accepted: in cases where the conditions cannot be seen prior to conclusion of the contract (because they are in the box with the product), there has been deemed to be consent if the consumer does not return the goods within 30 days (Hill v. Gateway (2000) Federal Circuit Court (7th Circuit). The problem here is that although there is this period of reflection and this is greater than is often available where terms are available just prior to purchase, even if consumers do take time to read the terms and decide they do not like them, there may be psychological and practical barriers that make it unlikely that consumers will actually send back the goods. For a recent discussion of Hill v. Gateway in the broader context of agreement and fairness rules, see A. Bagchi (2016), 'At the Limits of Adjudication: Standard Terms in Consumer Contracts', in L. Di Matteo and M. Hogg, Comparative Contract Law: British and American Perspectives, Oxford: OUP, 439, 441-2. 
However, in many countries law goes further than this within the procedural paradigm. A so-called 'red hand rule' is in force in a number of countries, this being designed to prevent a party sneaking onerous terms into a contract without the knowledge of the other party,. According to German law, surprising terms - terms which the other party would not have expected - are not binding. ${ }^{37}$ Such terms become effective only if the party who wishes to rely on them specifically informs the other party before the conclusion of the contract. Similar rules are to be found in other countries as well. ${ }^{38}$

The acceptance of a 'red hand rule' should not, however, be seen as a radical departure from a traditional procedural contract paradigm, but rather as an attempt to take such a paradigm seriously. ${ }^{39}$ The basic problem of a procedural paradigm is the fact that even informed consent, when given by a party in an inferior bargaining position, may not ensure that the contract is fair; so fairness in substance is not ensured by the 'red hand rule'. It therefore represents only a partial solution to the problems under consideration and does not eliminate the need for a substantive fairness provision. ${ }^{40}$

Traditionally courts have often tried to relieve the problems connected with the use of standard form conditions with the help of specific approaches to the interpretation of such conditions.

The rule on interpretation of standard form conditions in dubio contra

37 BGB $\S 305 \mathrm{c}(1)$.

${ }^{38}$ See for Austria, ABGB $\S 864 \mathrm{a}$; for England, for example Interfoto Picture Library v. Stiletto Visual Programmes [1988] 1 All ER 348 and AEG (UK) v. Logic Resource [1996] CLC 265; and for the Nordic countries, Bernitz (note 34), pp. 36 et seq., and Wilhelmsson (note 36), pp. 88 et seq. There is what appears to be a variation on this approach in the US Restatement of Contracts, s. 211 which says that a standard term is not part of the agreement if it is shown that the party relying on the term has reason to believe that the other party would not have assented to it if he had known of it. This appears less protective than the traditional red hand approach which simply focuses on the objective question as to whether the term is very unusual or unfair (if it is, special highlighting is required), while the US approach depends on the subjective perspective of the user of the term. However, it does, in common with the red hand approach, appear to give an incentive to traders to highlight terms that they should know are very unfair and that the other party would be unlikely to wish to agree to.

${ }^{39}$ Although a traditional freedom of contract approach committed to self- reliance and self-interest would still wish to minimise the steps that must be taken to make terms more transparent - see Willett (note 7), at 2.3.2.2.

${ }^{40}$ Indeed, another issue is whether the red hand rule applies to signed documents. Clearly, it should if the consumer is to be protected, as it hardly seems any more likely in practice that a consumer will have read and noticed a term simply because he signed the document. However, although the rule is applied to signed documents by the Canadian courts (see Tilden Rent-a-Car v. Glendinning (1978) 83 DLR (3d) 400, 18 OR (2d) 601 (CA); this is not the case in England (see L'Estrange v. Graucob [1934] 2 KB 934 and Peninsula Business Services v. Sweeney [2004] IRLR 49). 


\section{Handbook of research on international consumer law}

stipulatorem or contra proferentem is very widely accepted in European jurisdictions and in common law tradition. ${ }^{41}$ It has also been introduced into EC law in the context of consumer relations through the Unfair Contract Terms Directive. ${ }^{42}$

However, in this context, one may ask whether it is a good idea to restrict the scope of this rule only to standard form conditions (or terms not individually negotiated). One might also support a more general rule on interpretation, according to which contract terms 'supplied by one party' should be preferentially interpreted against that party. Such a rule always puts the party that was responsible for a lack of clarity at an interpretative disadvantage. ${ }^{43}$ In contrast to a rule restricted only to standard form conditions, such a general rule avoids conveyance of the impression that problems of balance due to one-sided drafting do not exist within less standardised contracts.

It is also worth mentioning the rule that individually negotiated terms take preference over standardised ones, which seems to be an equally generally accepted rule of interpretation. ${ }^{44}$. This rather self- evident rule can hardly be disputed. However, in consumer relationships it might, from an informational point of view, be useful to emphasise expressly, for example, that oral agreements can supersede standard form conditions.

\section{Individual fairness clauses blending procedural and substantive reasons}

We have already seen the ways in which rules on incorporation and interpretation can be formulated to deal purely with the transparency aspect of procedural fairness. We now turn to the possible approaches to a more general strategy that deals both with the issues of procedural fairness (including, but extending beyond, transparency) and fairness in substance. Within a fairnessoriented approach, the agenda is to balance the interests of the parties and in particular to protect the interests of the consumer. This means being cognisant of the ways in which terms may in substance be damaging to consumer interests; and the problems of procedural fairness that may arise.

${ }^{41}$ See, for example, as examples on legislation, the German BGB $\S 305 \mathrm{c}(2)$, the Austrian ABGB $\S 915$, the Italian CC Article 1370, UK cases such as Andrews Bros (Bournemouth) Ltd v. Singer \& Co [1934]1 KB 17 and Hollier v. Rambler Motors (AMC) Ltd [1972] 2 QB 71, and the US Restatement of Contracts, s. 206.

42 Article 5.

${ }^{43}$ See for example the extensive analysis by K. Huser (1983), Avtaletolking, Bergen, Oslo, Stavanger, Troms $\varnothing$ : Universitetsforlaget, pp. 553 et seq. For a general legislative formulation, see for example Austrian law, ABGB § 915 and Spanish law, CC Article 1288.

44 See for example BGB $\S 305 \mathrm{~b}$ and s. 211 of the US Restatement of Contracts. 
Looking at the issue from an international perspective, we find that the modern trend is to regulate unfairness and standard terms by use of a particular regulatory form - the 'general clause'. The precise expression of what is not accepted of course varies. So, within Europe the EU Unfair Contract Terms Directive standard is expressed as a test of 'unfairness' ${ }^{45}$ However, this is then defined in terms of 'significant imbalance' (focusing principally on the substance of the terms) and 'good faith' (focusing on both substance and the question of procedural fairness). ${ }^{46}$ Of course, EU law allows member states freedom in the way they express concepts deriving from Directives, so long as the substantive effects are achieved. So, we find that the Nordic countries have continued simply to refer to 'fairness' ${ }^{47}$ In Germany, focus is on 'good faith' and 'unreasonable disadvantage' (a model that also appears to focus on substance and procedure and that was strongly influential on the test used in the Unfair Contract Terms Directive). ${ }^{48}$ Originally, in the UK the 'fair and reasonable' test (covering substantive and procedural elements ${ }^{49}$ ) was used in the law that predated the EU Unfair Contract Terms Directive, ${ }^{50}$ while the law implementing the Directive copied out the test from the Directive. ${ }^{51}$ Now, however, following proposals by the Law Commissions there is a unified regime, which copies out the test from the Directive..$^{52}$

In other parts of the common law world, an important trend has been to use the concept of 'unconscionability' to regulate standard terms. ${ }^{53}$ This concept originates in the English law of equity and still exists in England. ${ }^{54}$ In England

\footnotetext{
45 Article 3.

46 See Willett (note 7), at 5.7-5.8.

47 Nordic Contracts Acts, Article 36.

48 Gesetz zur Modernisierung des Schuldrechts, BGB Article 307 (1).

49 See Willett (note 7), at 4.6.

50 Unfair Contract Terms Act 1977, s. 11.

51 Unfair Terms in Consumer Contracts Regulations 1999, regulation 5(1).

52 See English and Scottish Law Commissions (2005), above, note 15, at 21-

56, and Consumer Rights Act 2015, s. 62 (4).

53 See for example Uniform Commercial Code, 2-302 (US); Harry v. Kreutziger (1978) 95 DLR (3d) 231, 9 BCLR 166 (CA) (Canada); and Commercial Bank of Australia v. Amadio (1983) 151 CLR 447, 46 ALR 442 (HCA) and Trade Practices Act 1974, s. $51 \mathrm{AB}(2)$ (b) (Australia, until recently, but now see below). Generally on the US concept of unconscionability see Leff (note 7);; E.A. Farnsworth (2004), Contracts, 4th edition, Frederick, MD: Aspen Law and Business; and P.A. Alces (2016), 'The Death of Consent', in L. Di Matteo and M. Hogg, Comparative Contract Law: British and American Perspectives (note 38), 30, at 45-52.

${ }^{54}$ See generally M. Chen-Wishart (2015), Contract Law, 5th edition, Oxford: Oxford University Press, chapter 9 and cases such as Lloyds Bank v. Bundy [1975] 1 QB 326 (C.A), Alec Lobb (Garages) Ltd v. Total Oil (Great Britain) Ltd [1983] 1 WLR 87 and Boustany v. Piggott (1995) 69 P \& CR 298.
} 


\section{Handbook of research on international consumer law}

(and in the various other jurisdictions) the unconscionability concept tends (in common with the tests referred to above) to adopt a combined substantive and procedural analysis. ${ }^{55}$ In English law the approach is to consider whether the substantive terms are overreaching and oppressive and whether these are the result of the stronger party having taken advantage of the very vulnerable position of the other (weaker) party. ${ }^{56}$ This is one of the possible approaches in Canada; the other being whether the transaction as a whole is sufficiently out of line with community standards of commercial morality ${ }^{57}$ (an approach which seems sufficiently open textured to allow for consideration of both substantive and procedural elements). The US also focuses on unfairness in substance in combination with the question as whether there has been procedural fairness (with a dual procedural focus on whether there has been oppression and whether there has been 'unfair surprise', the latter being concerned, at least in part, with the question as to the transparency of the terms). ${ }^{58} \mathrm{In}$ Australia, unconscionability is also based on a combined procedural and substantive analysis. ${ }^{59}$ However, a particular problem with the unconscionability doctrine in general relates to whether it is capable of setting a reasonably high standard of protection. This is one reason that Australia has recently decided to tackle unfair terms in standard consumer contracts via a modern statutory test, at the core of which is the "significant imbalance' concept deriving from the EU Unfair Terms Directive. Later, we will develop this discussion as to the levels of protection offered by the various types of test.

Of course, in order to properly understand and regulate unfairness, we must go much further than just discussing the various phrases used in the general clauses and the broad idea of a procedural and substantive enquiry. Any rules need to be as clear as possible as to the type of problems being addressed and the way in which issues should interact within a test. Lack of certainty is a well- known concern in relation to assessments of fairness. This problem is affected in part by the kind of decision makers and standard setters involved in the process. Where adjudication takes place purely in the context of private law litigation, a key problem is that there will always tend to be a shortage of precedent upon which to base the structuring and development of an assessment of fairness. ${ }^{60} \mathrm{We}$ shall see later that this problem has been reduced by the fact that public and collective enforcement is also involved and this has

$55 \quad$ See Willett (note 7), at 8.1.2.

56 See Alec Lobb (Garages) Ltd v. Total Oil (Great Britain) Ltd [1983] 1 WLR

87 and Lloyds Bank v. Bundy [1975] 1 QB 326 (CA).

57 See Harry v. Kreutziger (1978) 95 DLR (3d) 231, 9 BCLR 166 (C), and for the development of the unconscionability doctrine in Canada from English law roots, see S. Waddams (2010), 'Abusive or Unconscionable Clauses from a Common Law Perspective' 49 Can Bus LJ 378. Note also the recent Canadian Supreme Court decision (Bhasin v Hrynew 2014 SCC 71) recognizing a general principle of good faith in Canadian contract law, and conceptualizing the rule against unconscionability as being a component of the duty of 'honest performance' that flowed from the good faith such a general duty; and the yet more recent case of Bank of Montreal v Javed 2016 ONCA 49 discussing the application of this duty to contractual performance.

58 See Uniform Commercial Code, 2-302 (US) (Official Commentary), J. Winn and M. Webber (2006), 'The Impact of EU Unfair Contract Terms Law on U.S. Business-to-Consumer Internet Merchants', The Business Lawyer, 1-20, p. 9, and Alces (note 55). 
59 See Commercial Bank of Australia v. Amadio (1983) 151 CLR 447, 46 ALR 442 (HCA).

60 See Collins (note 12), p. 293. 
contributed hugely to the development of the jurisprudence. Another factor contributing to clear and rational development of the law is the existence of specific guidelines for the application of whatever test is to be applied. ${ }^{61}$ However, quite apart from specific guidelines, there needs to be a more general overview of the types of factors that might be regarded as important; and how they should relate to one another.

As to types of terms covered by the general clauses, many of the general clauses have a broad scope. Indeed, the most effective model must be one that applies a general clause to all (except positively excluded) terms. This provides the flexibility to deal with any form of substantively unfair term that may be currently be in use, or that may be developed in the future. This approach was common in continental civil traditions and was adopted in the EU Unfair Contract Terms Directive. ${ }^{62}$ Of course, the challenge, then, is to reintroduce an element of certainty by seeking to work out what types of unfairness in substance such a test is most focused on.

This challenge is, for example in the EU Unfair Contract Terms Directive and the German tradition, dealt with (in part) by the use of a 'grey list' or 'indicative list' of terms that are particularly likely to be unfair. ${ }^{63}$ This clearly focuses all parties on the typically problematic terms; certainly in the UK

${ }^{61}$ The Unfair Contract Terms Directive has been criticised - in particular in common law quarters - for giving limited specific guidelines in relation to assessing fairness. There is a very bland reference to 'all the circumstances attending the conclusion of the contract and to all the other terms of the contract or of another contract on which it is dependent' (Article 4(1)). The Preamble (in discussing the good faith element of the test at Recital 16) also makes fairly vague references to dealing 'fairly and equitably' and taking into account the 'legitimate interests' of the consumer; although it does also make specific reference to the bargaining positions of the parties, whether the consumer received an inducement to agree to the term and whether the goods or services were supplied to the special order of the consumer. By contrast, in relation to the new UK regime, UK Law Commissions had proposed almost 30 specific guidelines on matters relating to the substance of the contract and the issues of transparency, choice and bargaining power; see English and Scottish Law Commissions (2005) (note ??), at 158-61. These were not included, however, in the regime finally adopted under the Consumer Rights Act 2015.

62 The test in the Directive applies to all terms except those specifically identified, that is, terms reflecting mandatory statutory or regulatory provisions (Article 1(2)), individually negotiated terms (Article 3(1)) and 'price' and 'main subject matter' terms (Article 4(2)).

${ }^{63}$ Article 3(3) and the Annex to the Directive and Gesetz zur Modernisierung des Schuldrechts, BGB Article 308. 
experience, it seems to have formed the focal point of much of the work of the enforcement bodies. ${ }^{64}$ However, such lists are never complete and it is necessary to seek to find some bridge between the list and the general clause - some form of guiding principle(s). One way to approach this issue is to use default rules (including implied terms) and remedies as benchmarks of fairness and to question in particular the fairness of terms that are detrimental to the consumer by comparison with such default rules or remedies. ${ }^{65}$ This approach is provided for explicitly in the German approach. ${ }^{66}$ In the first edition of this book, we argued that such an approach was implicit in the EU Unfair Contract Terms Directive: there typically being a significant imbalance to the detriment of the consumer where a term deviates from the default position. ${ }^{67}$ Now, this appears to have the support of the CJEU. In the case of the Mohamed Aziz, ${ }^{5}$ the Court states that the concept of 'significant imbalance' has to be 'assessed in the light of an analysis of the rules of national law' (i.e. the default rules) in order to determine to what extent the consumer is placed in a less favourable position (than these default rules).. ${ }^{68}$ The broad justification for such an approach is that default rules and remedies are based on some kind of balancing of the interests of the parties. ${ }^{69}$ So, for example, in English law rules on damages exist to compensate for the losses of the innocent party, but only in so far as these are not too remote ${ }^{70}$ and the innocent party has taken reasonable steps to mitigate his or her losses. ${ }^{71}$

However, there are not default rules dealing with every conceivable issue. For example, there is often no default rule dealing with whether and when the

${ }^{64}$ See, for example, the Office of Fair Trading (OFT) Guidance on Unfair Terms, 2001 and the many bulletins published by the OFT on enforcement of the law, and note that the new enforcement authority has carried over much of the practice of the OFT-see Capital Markets Authority (note 5), 58-9. Note also that in applying the concept of unfairness under the Unfair Terms Directive, although the CJEU tends to leave decisions on particular terms to national courts, it increasingly refers to paragraphs from the indicative list in its reasoning: e.g., Joined Cases C-240/98 to C244/98 Océano Grupo Editorial SA v Roció Murciano Quintero and Salvat Editores SA v José M. Sánchez Alcón Prades, José Luis Copano Badillo, Mohammed Berroane and Emilio Viñas Feliú [2000] ECR I-4941, para 22, Case C-137/08 VB Pénzügyi Lízing Zrt. v Ferenc Schneider [2010] ECR I-10847, para 54, Case C-472/10 Nemzeti Fogyasztóvédelmi Hatóság v Invitel Távközlési Zrt.[2012], paras 24-26, Case C-92/11 RWE Vertrieb AG v Verbraucherzentrale Nordrhein-Westfalen eV [2013], paras 46, 49 and 52, and Case C-415/11 Mohamed Aziz v Caixa d'Estalvis de Catalunya, Tarragona i Manresa (Catalunyacaixa) [2013], para 75.

$65 \quad$ See Willett (note 7), at 2.4.3.2.

${ }^{66}$ See the German BGB, $\S 307(2) 1$. We also tend to find a similar approach in other systems, for example, see Nebbia (note 30), p. 154 (Italy) and Beaulieu v. Day and Ross Inc [2005] NBJ No. 77 (CA) (Canada).

67 See Willett (note 7), at 5.7.3.

${ }^{68}$ This also seems to be broadly supported by the approach of the House of Lords (as it was, now the Supreme Court) in the UK: see in particular the judgement of Lord Bingham in First National Bank v DGFT 3 WLR 1297, 1307-8. 
69 Of course, not all default rules or implied terms are necessarily based on inter- est balancing. They may be based on presumed consent, the norms of the trading sector, business efficacy, economic efficiency, some combination of these criteria or on some other basis. On these issues, see generally C. Riley (2000), 'Designing Default Rules in Contract Law, Consent, Conventionalism and Efficiency', Oxford Journal of Legal Studies, 367-90. The simple point for present purposes is that default rules will often represent a more objective attempt to balance the interests of the parties than do terms drafted by the trader.

${ }^{70}$ Hadley v. Baxendale (1854) 9 Exch 341; Victoria Laundries (Windsor) Ltd v. Newman Industries 2 KB 528, CA; Koufos v. Czarnikow, The Heron II [1969] AC 350; Parsons (Livestock) Ltd v. Uttley Ingham \& Co Ltd [1978] QB 791, CA.

71 Payzu Ltd v. Sanders [1919] 2 KB 581, CA; Pilkington v. Wood [1953] Ch 770; Compania Financiera Soleada SA v. Hamoor Tanker Corp Inc, The Borag [1981] 1 WLR 274, CA. 
primary performance obligations of the parties can be altered or varied during the life of the contract. In such circumstances, an alternative possible benchmark of fairness is a concept of reasonable expectations. Does the term allow the trader to perform, or require the consumer to perform, in a way that is different from what the consumer would reasonably have expected? So, in the absence of a default rule, we seek to determine reasonable expectations from all the circumstances. It is arguable that this approach is implicit in the EU Unfair Contract Terms Directive; there being a significant imbalance where a term allows for compromise of the reasonable expectations of consumers. ${ }^{72}$ In practice, the European Court of Justice seems to have taken a step in this direction by ruling that in the assessment of unfairness 'it must be determined whether the seller or supplier, dealing fairly and equitably with the consumer, could reasonably assume that the consumer would have agreed to the term concerned in individual contract negotiations. ${ }^{6}$ This 'possible agreement test ${ }^{7}$ seems to be relatively close to a legitimate expectations test. The notion of reasonable expectations also appears to function as a benchmark of fairness in U.S. insurance law in particular. ${ }^{8}$

Of course, there remains a process of interest balancing. The focus may be on the expectations of the consumer, but these expectations must be objectively reasonable. In addition, it should be borne in mind that 'reasonable expectations' is a potentially very complex concept, there being considerable scope for debate, for example, as to the respective roles of empirical, normative and institutional elements in its makeup. ${ }^{73}$

Then we turn to the broader assessment as to unfairness in substance in the context of questions of procedure. As already suggested, broad clauses (for example, reasonableness, good faith) seem to accommodate such an analysis. So, for example, in the case of the EU Unfair Contract Terms Directive, deviation from a default rule or reasonable expectations (in amounting to a significant imbalance in rights and obligations) can then provide the trigger for a broader assessment of substance and procedure under the good faith element of the test. ${ }^{74}$

${ }^{72}$ See Willett (note 7), at 5.7.6. On the protection of the 'legitimate expectations' of consumers as a way of organizing our thinking about EU regulation of unfair terms, see T. Wilhelmsson, 'Unfair Contract Terms', in G. Howells, C. Twigg-Flesner and T. Wilhelmsson, Rethinking EU Consumer Law, (2017). More broadly on this as an emerging principle of EU consumer law, see for example H.-

W. Micklitz (1997), 'Legitime Erwartungen als Gerechtigkeitsprinzip des Europäischen Privatrechts', in L. Krämer, H.-W. Micklitz and K. Tonner (eds), Law and Diffuse Interests in the European Legal Order, Baden-Baden: Nomos, pp. 245-77; H.-W. Micklitz (1999/2000), 'Social Justice in European Private Law', Yearbook of European Law, Oxford: Clarendon Press, pp. 167-204 and G. Howells and T. Wilhelmsson (1997), EC Consumer Law, Aldershot: Ashgate, pp. 320-23. The

73 See C. Mitchell (1993), 'Leading a Life of its Own? The Roles of Reasonable Expectation in Contract Law', Oxford Journal of Legal Studies, 23(4), pp. 639-65 and Willett (note 7), at 4.4 and 5.7.3.

${ }^{6}$ Case C-415/11 Mohamed Aziz [2013], para 77.

7 Wilhelmsson (2017), section 5.

8 See Jones v. Horace Mann Insurance Co 937 P 2d (Alaska 1997) and Wheeler v. St Joseph Hospital 63 Cal. App 3d 345, 1976 Cal App. Lexis 2019, 133 Cal. Rptr. 775 (1976). 
${ }^{74}$ Generally on various ways of understanding the relationship between the elements of such tests, Beale (note 11), p. 245, R. Brownsword, G. Howells and T. Wilhelmsson (eds) (1994), Welfarism in Contract Law, Aldershot: Dartmouth; Bright (note 5), Chen-Wishart (note ??), chapter 9 and Nebbia (note 30), pp. 148-52. See also J.R. Peden (1982), The Law of Unjust Contracts, Sydney: Butterworths, p. 36 on the role of procedural and substantive elements in the US 


\section{Handbook of research on international consumer law}

Before turning to the procedural element in such analysis, we must say a bit more about substance. The fact that there is some deviation from the default rule or reasonable expectations does not necessarily mean that there is, conclusively, unfairness in substance. First of all, it seems that general clauses tend to allow for consideration of the particular type of substantive consumer interests affected by the term (for example, the way in which the term affects physical integrity, property and economic interests and interests in access to justice) ${ }^{75}$ Also, in relation to substance, the UK tradition has focused in particular on the question as to whether the trader or consumer was in a better position to have insured against the risk in question. ${ }^{76}$ Finally, a broad view of fairness in substance might ask whether there is another beneficial term that represents a 'fair price' for the detrimental term.

Taking into account the interests just mentioned seems to represent an attempt to achieve what we described above as commutative justice as between the parties. However, we also referred above to a fairness model in which there is a more distributive agenda, that is, where there is a focus on enhancing the position of weak groups of citizens in comparison with other groups. A general test of fairness, whether expressed in terms of good faith, reasonableness etc., does indeed seem sufficiently flexible to take account of the particularly vulnerable consumer who is in a weaker position than average when it comes to absorbing the consequences of particular substantive terms ${ }^{77}$ However, this approach is only likely to be taken consistently if the regime makes explicit reference to the relevant criteria relating to vulnerability (something that is not done, for example, in the EU Unfair Contract Terms Directive). Another necessary requirement of a distributive approach is that the general clause on fairness applies to the core price charged under the contract, as is the case in the Nordic system but not under the EU Unfair Contract Terms Directive. ${ }^{78}$ Without control of the price, traders can use the price to re-allocate to the consumer burdens transferred to the trader by distrib- 
utive policies that are applied to the ancillary terms. ${ }^{9}$ In addition, for any kind of comprehensive distributive agenda, there is a need for the rules to cover not only the fairness of the terms as at the time of conclusion of the contract, but also post-contractual circumstances. This is needed so that there may, for example, be recognition of the 'social force majeure' scenario described above

\footnotetext{
unconscionability doctrine and see the procedural and substantive elements set out in the Australian Consumer Law, s. 24.

75 See Willett (note 7), at 6.3.3.2.

76 Ibid., at 6.3.4.
}

See Willett (note 6), at 6.3.9 on the potential for taking such an approach under the EU Unfair Contract Terms Directive; and also see the CJEU decision in Case C-415/11 Mohamed Aziz [2013], where the CJEU declared contrary to the Unfair Terms Directive, a Spanish procedural rule preventing consumers from using the test of unfairness to challenge a term in a loan agreement in mortgage enforcement proceedings (..). One might argue that this approach is motivated to at least some degree by a desire to protect consumers who are especially vulnerable (in this case, in the sense that they stand to lose their home). Some have even interpreted this case-law as a judicial answer to the problems caused for European consumers by the financial crisis, so H.-W. Micklitz (2015), 'Conclusions: Consumer Over-Indebtedness and Consumer Insolvency - from Micro to Macro', in H.-W.Micklitz and I. Domurath (eds), Consumer Debt and Social Exclusion in Europe, Ashgate, 229-235, at p.233.

78 Article 4(2).

\section{9 : NB that the EU model does provide at least insist on the price being in plain and} intelligible language as a condition of it escaping the test of unfairness (art 4 (2)), and the CJEU has recently held that this requires that the term should not only be 'grammatically intelligible to the consumer', but the specific functioning of the term and the relationship to other terms of the contract should be set out transparently 'so that that consumer is in a position to evaluate, on the basis of clear, intelligible criteria, the economic consequences for him which derive from it.' (Case C-26/13 Árpád Kásler, Hajnalka Káslerné Rábai v OTP Jelzálogbank Zrt [2014]). The UK Consumer Rights Act has also insisted on a high level of transparency for the price-it must be 'transparent and 'prominent' (s. 64 (3)\& (4)). These transparency requirements are presumably intended at least to help increase the chances that the price is disciplined by market forces, but it is questionable whether charges contingent on later events (eg exceeding an overdraft limit, failing to check in online) will ever be sufficiently focused on by consumers to allow such market discipline. The new Australian regime appears to recognize this by refusing to treat such contingent charges as excluded price terms (Australian Consumer Law, s. 26 (1) (b), Commonwealth of Australia, Explanatory Memorandum to the Trade Practices Amendment (Australian Consumer Law) Bill (No 2) 2010, para 229). See C. Willett (2013), 'Transparency and Fairness in Australian and UK Regulation of Standard Terms', 37(1) University of Western Australia Law Review 72. 
(where the law protects consumers whose social circumstances have - postcontractually - become such that special protection is needed). Again, this approach is taken in Nordic law but not under the EU Unfair Contract Terms Directive, which focuses purely on the circumstances existing at the conclusion of the contract. ${ }^{79}$

It was also mentioned above that a fairness test may seek to further other societal policies. Some brief examples can be given here. In the particular context of the EU Unfair Contract Terms Directive, the good faith element of the test pays particular attention to the idea of solidarity amongst users, particularly where 'collective' services (that is, public services or services of general interest) are concerned. It is certainly arguable that this calls for special attention to be paid to notions of equality both in relation to access to the service and in relation to general treatment under the contract. This may, inter alia, imply a targeting of terms allowing for differential pricing and discriminatory approaches to variation or termination of the contract. ${ }^{80}$

In addition, a general clause such as that in the Unfair Contract Terms Directive may also be able to give particular emphasis to human rights interests. ${ }^{81}$ So, for example, terms may be particularly likely to be unfair where they impinge on rights of access to education or to private life and home (for example, terms allowing for withdrawal of education, eviction from property, forfeiture of property etc.). ${ }^{10}$

Turning to procedure, the logical approach to general clauses appears to be to view the substantive position in the light of procedural issues. A term is more likely to be fair, the greater the degree of procedural fairness, that is the more transparent the term was, the more choice was available and the more the consumer was in a stronger than normal bargaining position, such that he could have protected his interests at the time of the contract. The less evidence of such procedural fairness, the more likely the term will be unfair. Of course, given the fundamental role of consent in contract, it must surely be the case that transparency is the most fundamental aspect of procedural fairness. These sorts of approach to the interaction between substance and procedure appear to be accommodated within the test of unfairness in any general clause that is sufficiently flexible.

Of course, even if many of the tests we have been considering are broadly

\section{Article 4(1).}

${ }^{80}$ See Willett (note 7), at 6.3.5; and elsewhere in this volume, see Rott and Willett, Chapter 11.

${ }^{81}$ See S. Whittaker (2001), 'Judicial Review in Public Law and in Contract Law: The Example of "Student Rules"', Oxford Journal of Legal Studies, 193-217, at p. 213 and Willett (note 7), at 6.3.5.

${ }^{10}$ See above on the Aziz case protecting consumers at risk of losing their home. 
similar to the extent that they focus on a combined substantive/procedural analysis, the more specific approaches taken may differ in relation to the levels of (substantive and/or procedural) fairness required. So, for example, at one end of the spectrum, there is an approach setting a very low level of fairness; there only being a cause of action where the consumer is in a particularly weak position (that is, weaker than the average consumer) and this weakness is in some way taken advantage of by the imposition of extremely substantively unfair terms. This appears to be the approach under the English unconscionability concept and possibly under the Australian common law approach to unconscionability. ${ }^{82}$ Towards the other end of the spectrum is an approach that focuses on more routine unfairness (for example, unfairness in substance being found in significant - but not necessarily extreme - deviations from default rules and procedural unfairness being found in the routine lack of transparency and disparity of bargaining power as between traders and consumers generally). This seems to be the approach under the EU Unfair Contract Terms Directive ${ }^{83}$ under the modern statutory approach to unconscionability in Australia, and under the new Australian Consumer Law regime. ${ }^{84}$ The US approach is more difficult to pin down. It may be somewhere in the middle. Certainly, there are tendencies to look for more extreme unfairness, ${ }^{85}$ while the pattern is not necessarily wholly consistent, with a higher standard sometimes being set. ${ }^{86}$

Another question that may be asked goes very much to the interplay between procedure and substance; the question being whether a fairness test should be capable of finding a term to be unfair, based principally on its substantive features irrespective of procedural fairness. Of course, this can be done by a specific rule banning the term in question. However, general clauses like the good faith element of the EU Unfair Contract Terms Directive test seem flexible enough to achieve this result as well; the argument is that, while the procedural fairness weighs in favour of fairness, a particularly substantively detrimental term outweighs this and results in a finding of unfairness. ${ }^{87}$ This is particularly important, given the

82 See Commercial Bank of Australia v. Amadio (1983) 151 CLR 447, 46 ALR 442 (HCA) and D. Harland (1999), 'Unconscionable and Unfair Contracts: An Australian Perspective', in R. Brownsword, N. Hird and G. Howells (eds), Good Faith in Contract: Concept and Context, Aldershot: Ashgate, pp. 243-67.

${ }^{83}$ See Willett (note 7), at 3.4 and 8.1; but note that the open textured nature of general clauses allows for significant variations in approach based on national traditions and individual judicial ethics - see Willett, General Clauses and the Competing Ethics of EU Consumer law (note ??).

84 See Harland (note ??), at p. 249, and see the special edition of the University of Western Australia

Law Review ((2013) 37(1)) (note ??).

85 See Winn and Webber (note ??), pp. 9, 14-17.

86 Ibid., p. 17.

87 Ibid., at 6.5. 
likely limits in practice of procedural fairness. Even where terms are transparent, there are many good reasons to suppose that they will not be read and understood by consumers. ${ }^{88}$

The European Court of Justice appears to accept the idea that substantive fairness should be viewed as the dominant element in the good faith concept under the Unfair Contract Terms Directive. For example in both the Oceano and Freiburger cases, the CJEU said that where there is no benefit at all to a consumer then the term fails the test under the Unfair Contract Terms Directive. ${ }^{11}$ : If by 'benefit' the CJEU means a substantive benefit under the contract, the conclusion would appear to be that in such a case the term is unfair irrespective of the existence of procedural fairness. Further, in the Aziz case the Court in deciding whether imbalance arises 'contrary to the requirement of good faith', stated that what matters is whether this is a term that consumers would agree to if they could negotiate, which surely refers to what substantive term they would have agreed to. So, if the actual term used is significantly less substantively fair than this, it seems clear that the view of the CJEU is that such a term is in violation of the good faith requirement.

Notwithstanding this CJEU position, there remain questions as to whether such a departure from traditional freedom of contract thinking has yet been fully accepted at Member State level, in particular in the UK, where there seems to remain a reluctance to fully commit to the idea that terms can be unfair on substantive grounds even although they are transparent. ${ }^{12}$ At the same time, rather ironically, the European spirit of substantive fairness seems to have been more clearly embraced in Australia, where it appears that transparency cannot legitimize sufficiently substantively unfair terms. ${ }^{13}$

\section{Collective protection mechanisms}

Private law action against unfair terms only affects the use of the term in question as between the two parties to the action. Even if the term is set aside, there is nothing to prevent the trader continuing to use the term in contracts with other consumers. Costs and other deterrents to individual private law action will mean that there will only be relatively few private law actions. It is fairly self-evident that this form of enforcement will have a very limited impact on the use of unfair terms. This was indeed the case under the Unfair Contract Terms Act in the UK, which only provided for private law enforcement. Before the introduction of preventive control mechanisms under the regime implementing the Unfair Terms Directive, large numbers of terms that may well have failed the Unfair Contract Terms Act reasonableness test continued to be used. ${ }^{89}$

The obvious response is some form of preventive control. ${ }^{14}$ One possible

$11 \mathrm{~s}$ 3403.

12 The Functions of Transparency in Regulating Contract Terms: UK and Australian Approaches (2011), 60 (2), 355-385.

${ }^{13}$ Willett, 'Transparency and Fairness in Australian and UK Regulation of Standard Terms' (note ??); although see C. Willett, on whether it is yet

${ }^{14}$ In addition, the development of small claims procedures may also have an impact. The EU Unfair Contract Terms 
approach to this is a system within which standard terms can only be used when they are the product of negotiation and agreement (between traders and either a government agency or consumer organisations). Of course this has the advantage of dealing with the problem from the very beginning, preventing any unfair term being used in the first place and causing detriment. However, there are serious drawbacks: enormous resources may need to be devoted to

${ }^{88}$ On the limits of transparency generally, see G. Howells (2005), 'The Potential and Limits of Consumer Empowerment by Information?', Journal of Law and Society, 34970; Wilhelmsson (note 9), pp. 55-6 and Willett (note 7), at 2.4.3.4. Also, in this context, the work of the behavioural economists again becomes relevant - see Korobkin (note 13) and Della Vigna and Malmender (note 14).

${ }^{89}$ On the limits of private law, see I. Ramsay (2012), Consumer Law and Policy Text Cases and Materials on Regulating Consumer Markets, Oxford, UK and Portland, OR, US: Hart Publishing, $3^{\text {rd }}$ edn, p. 105-8. The Unfair Terms in Consumer Contracts Regulations 1994, then 1999 (now repealed and replaced by the unfair terms regime in the Consumer Rights Act 2015) were introduced to implement the Unfair Contract Terms Directive, which, as we shall see below, required (inter alia) preventive control mechanisms. The work of the Office of Fair Trading (now Competition and Markets Authority) under these Regulations revealed large numbers of exemption clauses (the largest single category of terms) still being used, despite the fact that very many of them would probably have failed the test under the Unfair Contract Terms Act 1977 (see the many examples in the Office of Fair Trading Bulletins on Unfair Terms published since 1994).

Directive has in practice, somewhat surprisingly, been used to remove and lower procedural thresholds and obstacles for consumer cases of this kind. The CJEU has in a long row of cases underlined the responsibility of the deciding court to react to unfairness ex officio, see more closely T. Wilhelmsson, 'Unfair Contract Terms' in G. Howells, C. Twigg-Flesner and T. Wilhelmsson, Rethinking EU Consumer Law (note xx), Section 6 and S. Weatherill (2013), EU Consumer Law and Policy, $2^{\text {nd }}$ ed., Edward Elgar, 157-158. 


\section{Handbook of research on international consumer law}

the process, and agreement may take a long time or never be achieved at all. ${ }^{90}$ Another possibility is for government to draft mandatory terms for all situations, precluding use of any other terms. However, this would require a huge investment of government time and would always be at risk of failing to cover all possible circumstances. The best that can be hoped for are less ambitious versions of this approach within which a certain number of compulsory terms are provided for, traders being free to use their own terms for other issues (subject, of course, to some other form of preventive control being used where the terms turn out to be unfair). ${ }^{91} \mathrm{~A}$ variant of this approach is one where consumer bodies draft terms and try to obtain the agreement of traders to use these terms. However, experience of this approach is not good, with the proposed terms often being rejected by traders. ${ }^{92}$

Within a system in which traders draft their own terms, the 'earliest' form of control comes where these terms cannot be used until they have been prevalidated by some government agency or by consumer bodies. A problem here is that this may be very time and resource-consuming for the body scrutinising the terms, given that they must cover all the proposed terms. Another possible model is one in which traders are free to use terms but may choose to submit them for approval to a government agency or consumer body. ${ }^{93}$ If the terms are approved, they are then free from public or private law challenge for a particular period, while if they are not approved, they cannot be used. A key problem with this approach is that the control is in the hands of the traders in that it is they who decide whether to submit terms for approval.

The model that has taken hold in the EU derives from Article 7 of the EU Unfair Contract Terms Directive, which requires member states to ensure that adequate and effective means exist to prevent the continued use of unfair terms, including provisions whereby persons or organisations may take action

90 See E. Hondius (1987), Unfair Terms in Consumer Contracts, Utrecht: Molengraaf Institut voor Privaatrecht, for a discussion of problems arising in the Dutch experience of negotiation between traders and consumer bodies.

91 Some terms are compulsory simply in the sense that they are default rules that cannot be excluded or restricted in any circumstances, although there is no actual obligation to set out the content of the terms in a written contract (see, for example, the approach to the terms as to description, quality and fitness for purpose in contracts for the sale and supply of goods, digital content and services in the UK (Consumer Rights Act 2015, ss. 31, 41 \& 57. It is very common in continental law to introduce partially mandatory rules for certain contract types, and it can be found in EU law as well, most notably in the EU Consumer Sales Directive.In other cases, there is an actual obligation to set out the content of the terms in a written contract (see, for example, the UK Consumer Credit Act, s. 61).

92 See C. Scott and J. Black (2000), Cranston's Consumers and the Law, 3rd edition, London: Butterworths, p. 101.

${ }^{93}$ See the Standard Contracts Law of 1964 in Israel and the discussion by S. Deutsch (1990), 'Control of Unfair Terms in Consumer Contracts in Israel: Law and Practice', Journal of Consumer Policy, pp. 188-99. 
according to the national law concerned before the courts or before competent administrative bodies for a decision as to whether contractual terms drawn up for general use are unfair, so that they can apply appropriate and effective means to prevent the continued use of such terms. This clearly requires that member states provide for some form of preventive action for injunctions to be taken against unfair terms. As to the main agents of such actions, there are considerable variations between the traditions prevailing in Europe; and these differences are recognised by the Directive (referring as it does to bodies 'recognised under national law' and to action being taken 'according to the national law concerned'). On the one hand, in many continental countries, such as Germany, consumer organisations have played and continue to play a decisive role, whilst in other countries various kinds of public bodies, such as the Nordic 'consumer ombudsmen' take action where terms being used are alleged to be unfair. ${ }^{94}$ In the UK, Art 7 was implemented by giving powers to a variety of bodies to seek injunctions to prevent the continued use of unfair terms about which there have been complaints. ${ }^{95}$ The main body is one closely linked to central government, the Competition and Markets Authority (CMA), which replaced the Office of Fair Trading (OFT) in 2014.

In practice, of course, what happens is that when a body such as the CMA or a consumer ombudsman receives a complaint and the conclusion is reached that the term is unfair, there is an attempt to negotiate the removal or amendment of the term, there only being a need for an injunction where such negotiation is unsuccessful. These powers have been a foundation for the enforcement bodies to persuade traders to remove or amend large numbers of terms. ${ }^{96}$ The broad consensus in the UK at least is that the OFT (now CMA) has been very successful in its role of removing unfair contract terms from the market. ${ }^{97}$ Clearly part of the reason for the success is the basic availability of powers to

94 See generally T. Wilhelmsson (1992), 'Administrative Procedures for the Control of Marketing Practices - Theoretical Rationale and Perspectives', Journal of Consumer Policy, 15(2), 159-77.

${ }_{95}$ Consumer Rights Act 2015, Sch. 2, art 3. In the Australian system, by contrast, only a government body (the Australian Competition and Consumer Commission) has injunctive powers - see Australian Consumer Law 2010-CHECK.

${ }^{96}$ See the Unfair Contract Terms Bulletins 1-29 covering cases dealt with from the passing of the initial 1994 Unfair Terms in Consumer Contracts Regulations until September 2004; and see the lists of Unfair Terms Cases with Undertakings that replaced the bulletins and run from October 2004 to the most recent in March 2006 (available on the Consumer Regulations Website, http://www.crw.gov.uk; accessed 31 July 2008).

97 See, for example, Bright (note 5), p. 331 and National Audit Office (1999), The Office of Fair Trading: Protecting the Consumer from Unfair Trading Practices, London: The Stationery Office, paras 17-19; but for a contrary view see C. Gillette (2005), 'Pre-approved Contracts for Internet Commerce', Houston Law Review, 9751013, at p. 987 in particular. 


\section{Handbook of research on international consumer law}

seek injunctions, that is, the fact that there is a legal sanction. However, another element is the fact that the OFT/CMA often negotiates with trade associations, avoiding the need to conduct too many separate negotiations and harnessing the desire of such associations to avoid bad publicity and to maintain good working relations with the OFT/CMA. ${ }^{98}$

The EU Unfair Contract Terms Directive even prescribes that collective legal remedies may be directed against business associations which use or recommend the use of general contractual terms. ${ }^{15}$

Following the tradition in many other European countries, injunctive powers in the UK are also available to a range of other bodies, such as the Consumers' Association (although these powers have not as yet been used). In the Nordic countries too, consumer associations have standing in these cases. Providing a role for bodies other than public ones clearly broadens the experience and expertise base and can also be seen as important to the democracy of the process. Of course it is also important that a system based on a multiplicity of enforcement bodies should be properly co-ordinated. This is vital if there is to be consistency and appropriate targeting in enforcement.

Another important dimension is the power of the enforcer (in the UK case, the OFT/CMA) to publish information and advice as to the operation of the system. ${ }^{99}$ In furtherance of these powers, the OFT/CMA have issued a considerable body of guidance on unfairness, which has informed their approach to enforcement. ${ }^{100}$ This has presumably aided traders and their advisers in understanding and complying with the law; ${ }^{101}$ and presumably also aided consumers and their advisers in recognising breaches of the law. This is of particular importance in a system of control based on a general clause (that is, in 'fleshing out' the detail of the way to understand and apply the broad - and potentially vague - general clause).

Another aspect to the approach applying in the UK is that in the shadow of the legal standards (and often in negotiation with the OFT/CMA) we find that trade bodies are developing model (and fair) standard terms. ${ }^{102}$ In fact there is another influence at work here: if codes of practice require the use of fair

\footnotetext{
98 See Bright (note 5), p. 335

99 See for the UK, Consumer Rights Act, Sch. 2, art 7.
}

100 Generally see the CMA website: https://www.gov.uk/government/organisations/competition-andmarkets-authority

The most notable general guidelines are those contained in the OFT Guidance of 2001. There have also been guidelines for particular sectors, for example, consumer entertainment contracts (2003), care home contracts (2003), home improvement contracts (2005), holiday caravan contracts (2005), and package holiday contracts (2004), and more recently, see the work carried out on unfair terms in health and fitness clubs (2013), on unfair terms related to late payment (2015), and the Unfair terms explained for businesses: individual guides (covering deposits, advance payments and cancellation 
charges, how and when a contract can be cancelled, excessive charges and disproportionate sanctions, exclusion and variation clauses, and subscriptions and automatic rollovers) (2016).

101 This is of particular importance given the traditional concerns as to the uncertainty caused by broad standards of fairness. Any such uncertainty may not only be a cost for businesses but may also make it more difficult for businesses to comply.

102 See, for example, the Kitchen Bedroom Bathroom Specialists Association model terms referred to by the Office of Fair Trading at http://www.oft.gov.uk/ news/press/2006/16-06.(CHECK-can't find anymore) 
terms, this improves the chances of the Code more generally receiving OFT approval. $^{103}$

\section{Conclusions: internationalisation}

Despite the different traditions of approaching the problem of unfair terms and standard form contracts, described above as four models of approach (the no particular problem model, the standard form contract model, the consumer protection model and the general fairness model), internationally there seems to be some convergence between the approaches, in particular in the field of consumer contracts. Those starting from a no particular problem model are implementing measures at least to protect consumers and the other models do not differ so much in the core area of the issue, that is with regard to the need to protect consumers against unduly detrimental standard terms. At least with regard to standard terms in consumer contracts, general clauses to combat unfairness are rather commonplace. While the general clauses may differ in expression they share a broad focus on the substance of the terms, the way in which they balance the interests of the parties and the way in which the agreement was brought about.

Still, of course there remain large differences reflecting national and regional traditions and priorities. So, there are, for example, differences in relation to the terms covered; how much focus is placed on procedural fairness and how much on fairness in substance; and, indeed, what exactly amounts to procedural fairness and fairness in substance.

From the perspective of regional and international trade this state of affairs has caused concern. The existence of different fairness regimes affecting consumer contracts in different countries is regarded as an obstacle to trade between these countries. Traders that plan to market their products and services across borders are thought to experience higher transaction costs as they need to check their terms with regard to different national regimes. They may also face 'hidden traps' ${ }^{104}$ in foreign countries which they could not foresee. Some also claim that consumers are put off shopping across borders and making use of enlarged regional markets because of lack of trust in varying

${ }^{103}$ See s. 8 of the Enterprise Act in the UK which allows the OFT to approve codes and allow the use of a symbol of this approval. The criteria for approval include transparency and fairness in relation to contract terms - see Office of Fair Trading (2001), OFT's Core Criteria for the New Approach to Codes of Practice, in the Office of Fair Trading response to the consultation on Codes of Practice, Annex C, at 3(c).CHECK

${ }^{104}$ This term is taken from H. Beale (2002), 'Finding the Remaining Traps instead of Unifying Contract Law', in S. Grundmann and J. Stuyck (eds), An Academic Green Paper on European Contract Law, The Hague: Kluwer Law International, pp. $67-72$. 
foreign fairness rules. ${ }^{105}$ Even though these claims usually are not based on any convincing empirical evidence, they have led to regional harmonisation movements. The adoption of the EU Unfair Contract Terms Directive, attempting to harmonise the rules on unfair contract terms in consumer contracts in the member states, is probably the best example of such efforts.

However, even within the EU, despite the Directive, there remain differences. First of all, the Directive is a minimum Directive, allowing member states to maintain or adopt higher levels of protection. ${ }^{106}$ So, for example, the Nordic countries have chosen to take advantage of this to maintain their more fully fledged protectionist approach and continue to apply the fairness test to individually negotiated terms and to the core terms of the contract. Secondly, even within the general clause, there is such flexibility that it is inevitable that national courts, drawing on national tradition and perspective, will take varying approaches to the issues of proce- dure and substance, their interaction and their application to specific terms. This scope for variation appears likely to be supported by the European Court of Justice. The line taken appears to be that there will only be interference with the approach taken by national courts where the term is wholly to the benefit of the trader, there being no benefit in the term (or elsewhere in the contract) for the consumer. Where any such benefit is identified by the European Court of Justice, the suggestion is that it will be left to the national court to apply the test to the term within the national legal context. 109 In later years, however, the European Court of Justice seems to have been more engaged in building at least some features of a European doctrine of fairness. ${ }^{16}$

The above discussion reveals that harmonisation by reference to general clauses on unfairness is unlikely to produce identical approaches to unfairness and identical standard terms in different countries. Of course, this may be viewed as desirable to the extent that one considers it important to retain scope for national legal traditions to flourish and for local expectations as to fairness to be reflected. ${ }^{110}$ However, to the extent that there is an agenda to eliminate barriers to trade, there is a potential problem. One solution to this may lie in

${ }^{105}$ For a criticism of this claim, see T. Wilhelmsson (2004), 'The Abuse of the "Confident Consumer" as a Justification for EC Consumer Law', Journal of Consumer Policy, 317-37.

106 See Article 8.

107 Regulations 5(1) and 6(2).

108 See English and Scottish Law Commissions (2005), at 31-5.

109 Freiburger Kommunalbauten v. Hofstetter, Case C-237/02, ECR [2004] I3403. This reasoning is followed up in other cases, for example Case C-76/10 Pohotovost' s.r.o. v Iveta Korčkovská [2010] ECR I-11557 (penalty clause in credit agreement) and Case C-472/10 Nemzeti Fogyasztóvédelmi Hatóság v Invitel Távközlési Zrt. [2012] (term on unilateral amendment of fees for a service).

${ }^{110}$ See many of the contributions in T. Wilhelmsson, E. Paunio and A. Pohjolainen (eds) (2007), Private Law and the Many Cultures of Europe, The Hague: Kluwer Law

${ }^{16} \mathrm{H}$-W. Micklitz and N. Reich (2014), 'The Court and Sleeping Beauty: The Revival of the Unfair Contract Terms Directive (UCTD)', 51 CMLR, 771-808. 
International. 
more rigorous co-operation in standard setting and enforcement as between the national regulatory bodies. In the EU, closer cooperation between enforcement agencies is indeed promoted. ${ }^{111}$ A more far-reaching and distant solution is to step further from harmonising the unfairness regimes towards unifying parts of contract law in general. Indeed, one of the starting points for the work on a harmonised European contract law that started promisingly ${ }^{112}$ but now has more or less faded, ${ }^{17}$ was the insight that a harmonisation of unfairness rules does not, in itself, eliminate the differences.

As general unification of consumer contract law is not an issue for the immediate future, ${ }^{113}$ certainly globally but also regionally, ${ }^{18}$ in cross-border trade, choice of law rules will continue to play a role. In consumer relationships, the use of such highly developed and technical rules is of course deplorable, but can probably not be avoided.

Anyway, also in the rules concerning private international law the need for consumer protection is often reflected to some extent. From a consumer

111 See Regulation 2006/2004 on cooperation between national authorities responsible for the enforcement of consumer protection laws (the Regulation on Consumer Protection Cooperation), OJ L364/1.

112 Three Communications of the Commission laid the foundations for the present work: Communication from the Commission to the Council and the European Parliament on European Contract Law, COM(2001) 398 final, Communication from the Commission to the European Parliament and the Council, A More Coherent European Contract Law. An Action Plan, COM(2003) 68 final and Communication from the Commission to the European Parliament and the Council, European Contract Law and the revision of the acquis: the way forward, COM(2004) 651 final. The literature on the subject is already vast; a reference to the 'paradigmatic' collections is sufficient in this context: A. Hartkamp et al. (eds) (2004), Towards a European Civil Code, 3rd edition, Nijmegen: Ars Aequi Libri and S. Grundmann and J. Stuyck (eds), An Academic Green Paper on European Contract Law, The Hague: Kluwer Law International, pp. 67-72. Interesting multidisciplinary analyses can be found in J. Smits (ed.) (2005), The Need for a European Contract Law, Groningen: Europa Law Publishing.

113 The most important international convention in the area, The United Nations Convention on Contracts for the International Sale of Goods, does not apply to consumer contracts (Article 2(a)).

114 See in this volume the chapter by Rothchild and Quirk, Chapter 12.

${ }^{17}$ But resulting in the Draft Common Frame of Reference. Principles, Definitions and Model Rules of European Private Law (Sellier 2009).

${ }^{18}$ In EU plans for a comprehensive Consumer Rights Directive, consolidating unfair contract terms legislation and other consumer contracts legislation in one maximum directive, did not lead to the intended broad results. Cpr the Proposal for a Directive of the European parliament and of the Council on consumer rights $\operatorname{COM}(2008) 614$ with the resulting Directive 2011/83/EU on consumer rights, containing mostly only provisions on details concerning information and cooling-off periods in certain situations. 
protection perspective, one important point is to ensure that a choice of law clause does not deprive the consumer of protection by selecting a less protective regime. The EU Unfair Contract Terms Directive provides expressly that member states should ensure that a consumer does not lose the protection of the Directive by virtue of a choice of law of a non-member state if a contract has a close connection with the territory of one of the member states. ${ }^{115}$ More generally, within the EU, the Rome Convention on the Law Applicable to Contractual Obligations states that within certain consumer contracts a choice of law shall not have the result of depriving the consumer of the protection afforded to him by the mandatory rules of the country in which he has his habitual residence. ${ }^{116}$ Secondly, even where no choice of law clause is used in the contract, the rules of private international law should ensure that the consumer is not unexpectedly confronted with rules from a jurisdiction he did not anticipate. Also in this respect, the Rome Convention provides that the said consumer contracts shall be governed by the law of the consumer's habitual residence. ${ }^{117}$ However, the definition of the consumer contracts covered by these particular provisions of the Rome Convention is limited. So, for example, in cases where the consumer contracts from his country of residence with a trader in another country, he is only protected by the Rome Convention where the contract was preceded by a specific invitation or by advertising. In addition, the Rome Convention only ever provides that a consumer cannot be deprived of the protective regime of his country of habitual residence. This would not protect a consumer from a non-EU country who is only temporarily resident in an EU country. More comprehensive protection for consumers is indeed proposed in the UK. ${ }^{118}$ This may to some extent be seen to address the problem discussed above to the effect that differing approaches to the fairness concept as between member states may undermine consumer confidence in the use of the European market. However, irrespective of the chosen solution, a recurrent application of complicated choice of law rules does not appear to be a very efficient means of protecting small-scale contractors like consumers.

It is likely that the problems related to lack of harmonisation and choice of law will become more acute and difficult in the years to come. The problems related to the regionalisation and internationalisation of consumer markets are becoming particularly acute in the rapidly growing field of e-commerce. In this area, both the general problem of keeping a sufficient level of consumer protection irrespective of where the trader operates, as well as difficult legal issues related to choice of law and jurisdiction, appear to be almost unsolvable, and call for particular solutions. These will be discussed, however, elsewhere in this volume. ${ }^{114}$

\section{Bibliography}

Adams, J. (1994), 'Unconscionability and the Standard Form Contract', in R. Brownsword, G. Howells and T. Wilhelmsson (eds), Welfarism in Contract Law, Aldershot: Dartmouth, pp. $230-47$.

Alces, P.A. (2016), 'The Death of Consent', in L. Di Matteo and M. Hogg, Comparative Contract Law: British and American Perspectives, Oxford: OUP, 30,

Atiyah, P. (1986), Essays on Contract, Oxford: Clarendon Press.

Bagchi, A. (2016), 'At the Limits of Adjudication: Standard Terms in Consumer Contracts', in L. 
Di Matteo and M. Hogg, Comparative Contract Law: British and American Perspectives, Oxford: OUP, 439. 


\footnotetext{
115 Article 6(2).

116 Article 5(2).

117 Article 5(3).

118 Seee English and Scottish Law Commissions (2005), at 111-5.
} 
Beale, H. (1995), 'Legislative Control of Fairness: The Directive on Unfair Terms in Consumer Contracts', in J. Beatson and D. Friedmann, Good Faith and Fault in Contract Law, Oxford: Clarendon, pp. 231-61

Beale, H. (2002), 'Finding the Remaining Traps instead of Unifying Contract Law', in S. Grundmann and J. Stuyck (eds), An Academic Green Paper on European Contract Law, The Hague: Kluwer Law International, pp. 67-72.

Benson, P. (2001), 'The Unity of Contract Law', in P. Benson (ed.), The Theory of Contract Law, Cambridge: Cambridge University Press, pp. 118-205.

Bernitz, U. (1993), Standardavtalsrätt, 6th edition, Stockholm: Marknadsrättsförlaget.

Bigwood, R. (2011-2012) 'Fairness Awry? Reflections on the BCLI Report on Proposals for Unfair Contract Terms Relief', 52 Can. Bus. L.J. 197.

Brandner, H.E. and P. Ulmer (1991), 'The Community Directive on Unfair Terms in Consumer Contracts: Some Critical Remarks on the Proposal Submitted by the EC Commission', Common Market Law Review, 647-62.

Bridge, M. (1999), 'Good Faith in Commercial Contracts', in R. Brownsword, N. Hird and G Howells (eds), Good Faith in Contract: Concept and Context, Aldershot: Ashgate, pp. 139-64.

Bright, S. (2000), 'Winning the Battle against Unfair Contract Terms', Legal Studies, 331-52.

Brownsword, R., G. Howells and T. Wilhelmsson (eds) (1994), Welfarism in Contract Law, Aldershot: Dartmouth.

Chen-Wishart, M. (2007), Contract Law, 2nd edition, Oxford: Oxford University Press.

Calfaggi, F. and Micklitz, H.-W. (2007), 'Administrative and Judicial Collective Enforcement of Consumer Law in the U.S. and the European Community', EUI LAW Working Paper, No. 2007/22, 1-49.

Collins, H. (1999), Regulating Contracts, Oxford: Oxford University Press.

Della Vigna, S. and U. Malmendier (2006), 'Paying Not to Go to the Gym', American Economic Review, 694-719.

Deutsch, S. (1990, 'Control of Unfair Terms in Consumer Contracts in Israel: Law and Practice', Journal of Consumer Policy, 188-99.

Eisenberg, M. (1982), 'The Bargain Principle and its Limits', Harvard Law Review, 741-801.

European Commission, Report from the Commission on the Implementation of Council Directive 93/13/EEC of 5 April 1993 on Unfair Terms in Consumer Contracts, COM(2000) 248 final.

Farnsworth, E.A. (2004), Contracts, 4th edition, Frederick, MD: Aspen Law and Business.

Faure, M.G. and H.A. Luth (2011), 'Behavioural Economics in Unfair Contract Terms: Cautions and Considerations', 34 Journal of Consumer Policy, 337-358,

Freilich, A. and E. Webb (2013), 'Small Business - Forgotten and in Need of Protection from

Unfairness', 37 University of Western Australia Law Review, 134.

Gillette, C. (2005), 'Pre-Approved Contracts for Internet Commerce', Houston Law Review, 975-1013.

Goldberg, V. (1974), 'Institutional Change and the Quasi-Invisible Hand', Journal of Law and Economics, 461-92.

Gordley, J. (1981), 'Equality in Exchange', California Law Review, 1587-656.

Grundmann, S. and J. Stuyck (eds) (2002), An Academic Green Paper on European Contract Law, The Hague: Kluwer Law International.

Harland, D. (1999), 'Unconscionable and Unfair Contracts: An Australian Perspective', in R. Brownsword, N. Hird and G. Howells (eds), Good Faith in Contract: Concept and Context, Aldershot: Ashgate, pp. 243-67.

Hartkamp, A. et al. (eds) (2004), Towards a European Civil Code, 3rd edition, Nijmegen: Ars Aequi Libri.

Hondius, E. (1987), Unfair Terms in Consumer Contracts, Utrecht: Molengraaff Institut for Private Law.

Howells, G. (2005), 'The Potential and Limits of Consumer Empowerment by Information?', Journal of Law and Society, 349-70.

Howells, G. and T. Wilhelmsson (1997), EC Consumer Law, Aldershot: Ashgate.

Howells, G., C.Twigg-Flesner.and T.Wilhelmsson (2017), Rethinking EU Consumer Law, Ashgate.

Huser, K. (1983), Avtaletolking, Bergen, Oslo, Stavanger and Troms $\varnothing$ : Universitetsforlaget.

Johnston, J. (2006), 'The Return of Bargain: An Economic Theory of How Standard Form Contracts Enable Co-operative Negotiation Between Businesses and Consmers', Michigan Law Review, 857-98.

Kessler, F. (1943), 'Contracts of Adhesion: Some Thoughts about Freedom of Contract', Columbia Law Review, 629-42. 
Korobkin, R. (2003), 'Bounded Rationality, Standard Form Contracts and Unconscionability', University of Chicago Law Review, 1203-95. 


\section{Handbook of research on international consumer law}

Leff, A. (1967), 'Unconscionability and the Code: The Emperor's New Clause', University of Pennsylvania Law Review, 485-559.

Leff, A. (1970), 'Contract As Thing', American University Law Review, 131-57.

Micklitz, H.-W. (1997), 'Legitime Erwartungen als Gerechtigkeitsprinzip des Europäischen Privatrechts', in L. Krämer, H.-W. Micklitz and K. Tonner (eds), Law and Diffuse Interests in the European Legal Order, Baden-Baden: Nomos, pp. 245-77.

Micklitz, H.-W. (1999/2000), 'Social Justice in European Private Law', Yearbook of European Law, Oxford: Clarendon Press, 167-204.

Micklitz, H.-W. (2015), 'Conclusions: Consumer Over-Indebtedness and Consumer Insolvency from Micro to Macro', in H.-W.Micklitz and I. Domurath (eds), Consumer Debt and Social Exclusion in Europe, Ashgate, 229-235.

Micklitz, H.-W. and N. Reich (2014), 'The Court and Sleeping Beauty: The Revival of the Unfair Contract Terms Directive

(UCTD)', 51 CMLR, 771-808.

Mitchell, C. (1993), 'Leading a Life of its Own? The Roles of Reasonable Expectation in Contract Law', Oxford Journal of Legal Studies, 23(4), 639-65.

National Audit Office (1999), The Office of Fair Trading: Protecting the Consumer from Unfair Trading Practices, London: The Stationery Office

Nebbia, P. (2007), Unfair Contract Terms in European Law, Oxford: Hart Publishing.

Nogler, L. and U. Reifner (eds) (2014), Life Time Contracts. Social Long-term Contracts in Labour, Tenancy and Consumer

Credit Law, Eleven international publishing.

Office of Fair Trading (2001a), 'Unfair Contract Terms Guidance: Introduction', London: OFT.

Office of Fair Trading (2001b), 'OFT's Core Criteria for the New Approach to Codes of Practice, in the Office of Fair Trading response to the consultation on Codes of Practice, Annex C, London: OFT.

Peden, J.R. (1982), The Law of Unjust Contracts, Sydney: Butterworths.

Rakoff, T.D. (1983), 'Contracts of Adhesion: An Essay in Reconstruction, 96, Harvard Law Review, 1173-284.

Ramsay, I. (2006), 'Consumer Law, Regulatory Capitalism and the New Regulation', Sydney Law Review, 9-35.

Ramsay, I. (2007), Consumer Law and Policy Text Cases and Materials on Regulating Consumer Markets, Oxford, UK and Portland, OR, US: Hart Publishing.

Riley, C. (2000), 'Designing Default Rules in Contract Law, Consent, Conventionalism and Efficiency', Oxford Journal of Legal Studies, 367-90.

Schiek, D. (2000), Differenzierte Gerechtigkeit, Baden-Baden: Nomos.

Scott, C. and J. Black (2000), Cranston's Consumers and the Law, 3rd edition, London: Butterworths.

Smith, S. (2003), Contract Theory, Oxford: Oxford University Press.

Smits, J. (ed.) (2005), The Need for a European Contract Law, Groningen: Europa Law Publishing.

Sunstein, C.R. and R.H. Thaler, 'Libertarian Paternalism is Not an Oxymoron', The University of Chicago Law Review, 1159-1202.

Teubner, G. (1998) 'Legal Irritants: Good Faith in British Law or How Unifying Law Ends Up in New Divergences', Modern Law Review 61, 11-32.

Trebilcock, M. (1980), 'An Economic Approach to the Doctrine of Unconscionability', in B. Reiter and J. Swann (eds), Studies in Contract Law, Toronto: Butterworths, pp. 390-421.

Waddams, S. (2010), 'Abusive or Unconscionable Clauses from a Common Law Perspective' 49 Can Bus LJ 378.

Weatherill, S. (2013), EU Consumer Law and Policy, $2^{\text {nd }}$ ed., Edward Elgar.

Whitford, W. (1995), 'Contract Law and the Control of Standardized Terms in Consumer Contracts: An American Report', European Review of Private Law, 193-210.

Whittaker, S. (2001), 'Judicial Review in Public Law and in Contract Law: The Example of "Student Rules”, (2001) Oxford Journal of Legal Studies, 193-217.

Wightman, J. (2003), 'Beyond Custom: Contracts, Contexts and the Recognition of Implicit Understandings', in D. Campbell, H. Collins and J. Wightman, Implicit Dimensions of Contract, Oxford: Hart Publishing, pp. 143-86.

Wilhelmsson, T. (1990), “'Social Force Majeure” - A New Concept in Nordic Consumer Law', Journal of Consumer Policy, 13, 1-14.

Wilhelmsson, T. (1992), 'Administrative Procedures for the Control of Marketing Practices -Theoretical Rationale and Perspectives', Journal of Consumer Policy, 15(2), 159-77.

Wilhelmsson, T. (2008), Standardavtal och oskäliga avtalsvillkor, 3rd edition, Helsingfors:

Talentum.

Wilhelmsson, T. (2004), 'The Abuse of the "Confident Consumer" as a Justification for EC 
Consumer Law', Journal of Consumer Policy, 317-37.

Wilhelmsson, L. (2006), 'Cooperation and Competition Regarding Standard Contract Terms in Consumer Contracts', European Business Law Review, 49-72.

Wilhelmsson, T., E. Paunio and A. Pohjolainen(eds) (2007), Private Law and the Many Cultures of Europe, The Hague: Kluwer Law International. 
Willett, C. (2007), Fairness in Consumer Contracts: The Case of Unfair Terms, Aldershot: Ashgate.

Willett, C. (2012) 'General Clauses and the Competing Ethics of EU Consumer Law in the UK', 71 Cambridge Law Journal, 412-440.

Willett, C. (2013), 'Transparency and Fairness in Australian and UK Regulation of Standard Terms', 37(1) University of Western Australia Law Review 72

Winn, J. and M. Webber (2006), 'The Impact of EU Unfair Contract Terms Law on U.S. Business-to-Consumer Internet Merchants', The Business Lawyer, 1-20.

Zimmermann, R. (2005), 'Consumer Contract Law and General Contract Law: The German Experience’, Current Legal Problems, 415-89. 